\title{
The Repertoire of $\mathrm{Na}$,K-ATPase $\alpha$ and $\beta$ Subunit Genes Expressed in the Zebrafish, Danio rerio
}

\author{
S. Johannes R. Rajarao, ${ }^{1}$ Victor A. Canfield, ${ }^{1}$ Manzoor-Ali P.K. Mohideen, ${ }^{2}$ \\ Yi-Lin Yan, ${ }^{3}$ John H. Postlethwait, ${ }^{3}$ Keith C. Cheng, ${ }^{2}$ and Robert Levenson ${ }^{1,4}$ \\ ${ }^{1}$ Department of Pharmacology and ${ }^{2}$ The Jake Gittlen Cancer Research Institute and Department of Pathology, Pennsylvania \\ State College of Medicine, Hershey, Pennsylvania 17033, USA; ${ }^{3}$ Institute of Neuroscience, University of Oregon, Eugene, \\ Oregon 97403, USA
}

\begin{abstract}
We have identified a cohort of zebrafish expressed sequence tags encoding eight Na,K-ATPase $\alpha$ subunits and five $\beta$ subunits. Sequence comparisons and phylogenetic analysis indicate that five of the zebrafish $\alpha$ subunit genes comprise an $\alpha$ l-like gene subfamily and two are orthologs of the mammalian $\alpha 3$ subunit gene. The remaining $\alpha$ subunit clone is most similar to the mammalian $\alpha 2$ subunit. Among the five $\beta$ subunit genes, two are orthologs of the mammalian $\beta 1$ isoform, one represents a $\beta 2$ ortholog, and two are orthologous to the mammalian $\beta 3$ subunit. Using zebrafish radiation hybrid and meiotic mapping panels, we determined linkage assignments for each $\alpha$ and $\beta$ subunit gene. $\mathrm{Na}, \mathrm{K}$-ATPase genes are dispersed in the zebrafish genome with the exception of four of the $\alpha$-like genes, which are tightly clustered on linkage group 1. Comparative mapping studies indicate that most of the zebrafish $\mathrm{Na}, \mathrm{K}-\mathrm{ATP}$ ase genes localize to regions of conserved synteny between zebrafish and humans. The expression patterns of $\mathrm{Na}, \mathrm{K}-\mathrm{ATPase} \alpha$ and $\beta$ subunit genes in zebrafish are quite distinctive. No two $\alpha$ or $\beta$ subunit genes exhibit the same expression profile. Together, our data imply a very high degree of $\mathrm{Na}, \mathrm{K}-\mathrm{ATPase}$ isoenzyme heterogeneity in zebrafish, with the potential for 40 structurally distinct $\alpha / \beta$ subunit combinations. Differences in expression patterns of $\alpha$ and $\beta$ subunits suggest that many of the isoenzymes are also likely to exhibit differences in functional properties within specific cell and tissue types. Our studies form a framework for analyzing structure function relationships for sodium pump isoforms using reverse genetic approaches.
\end{abstract}

\begin{abstract}
$\mathrm{Na}, \mathrm{K}-\mathrm{ATPa}$ e is an integral membrane protein responsible for establishing and maintaining the electrochemical gradients of sodium and potassium ions across the plasma membrane of virtually all animal cells (Cantley 1981). The enzyme is composed of equimolar amounts of $\alpha$ and $\beta$ subunits (Jørgensen 1974). The $\alpha$ subunit contains the catalytic site for ATP hydrolysis and is the cellular receptor for cardiac glycoside drugs such as ouabain and digitalis (Jørgensen 1974; Cantley 1981). The $\beta$ subunit is a glycosylated polypeptide that is an essential component of Na,K-ATPase (Cantley 1981). However, the exact role of the $\beta$ subunit in the activity of the enzyme has not yet been established.

$\mathrm{Na}$,K-ATPase $\alpha$ and $\beta$ subunits are each encoded by multigene families. Molecular cloning has identified four $\alpha$ and three $\beta$ subunit genes in humans and rodents (Levenson 1994; Shamraj and Lingrel 1994; Malik et al. 1998; Underhill et al. 1999). Human genome sequencing projects have not revealed any previously unidentified $\mathrm{Na}$, K-ATPase subunits. The $\alpha$ and $\beta$ subunit genes are dispersed in the mouse genome, with the exception of the $\alpha 2$ and $\alpha 4$ genes which are very tightly linked on chromosome 1 (Levenson 1994; Besirli et al. 1998; Underhill et al. 1999). Analysis of the expression profiles of $\alpha$ and $\beta$ subunits indicates that each gene is expressed in a distinct tissue- and cell-specific fashion. The $\alpha 1$ subunit is ubiquitously expressed (Shyjan and Levenson 1989). The $\alpha 2$ subunit shows predominant expression in
\end{abstract}

${ }^{4}$ Corresponding author.

E-MAIL rlevenson@hmc.psu.edu; FAX (717) 531-5013.

Article and publication are at www.genome.org/cgi/doi/10.1101/ gr. 186001. brain, heart, and skeletal muscle, whereas the $\alpha 3$ subunit is restricted to tissues of neural origin (Shyjan and Levenson 1989; Cameron et al. 1994). Expression of the $\alpha 4$ subunit has so far been detected exclusively in the epididymis and testis (Underhill et al. 1999; Woo et al. 1999). Na,K-ATPase $\beta$ subunit isoforms also exhibit distinct expression patterns. The $\beta 1$ and $\beta 3$ subunits are ubiquitously expressed, whereas the $\beta 2$ isoform is expressed predominantly in brain (Shyjan and Levenson 1989; Malik et al. 1996, 1998). Chromosomal dispersion of the $\alpha$ and $\beta$ subunit genes, coupled with their distinct expression patterns, suggests specialized functional roles for each of the $\alpha$ and $\beta$ subunit isoforms.

Analysis of Na,K-ATPase expressed in heterologous systems has suggested that $\alpha / \beta$ subunit interaction is promiscuous (Jewell and Lingrel 1991; Lemas et al. 1994; Crambert et al. 2000), and that as many as 12 structurally distinct isoenzymes may exist. However, the functional significance for this high degree of isoenzyme diversity remains enigmatic. Comparison of the biochemical properties of alternate $\alpha / \beta$ subunit combinations has so far revealed only subtle functional differences between isoenzymes (Jewell and Lingrel 1991; Crambert et al. 2000). The analysis of mice carrying targeted mutations in the $\alpha 1$ and $\alpha 2$ subunit genes has suggested important functional differences between these genes in the regulation of cardiac contractility. The basis for these functional differences has not yet been clearly explained.

To better understand the function of distinct $\mathrm{Na}, \mathrm{K}-$ ATPase isoenzymes, we have initiated studies designed to characterize Na,K-ATPase genes expressed in the zebrafish, Danio rerio. Zebrafish is an excellent model system for study- 
ing vertebrate development and gene function. In addition, reverse genetic techniques have been developed that provide powerful approaches to the analysis of the physiological function of expressed genes. We describe the cloning and characterization of a cohort of sodium pump genes from the zebrafish. Of this cohort, eight cDNAs encode $\alpha$ subunit isoforms and five encode distinct $\beta$ subunit isoforms. We have mapped the positions of the $\alpha$ and $\beta$ subunit genes in the zebrafish genome, and examined expression profiles of each of the genes in a panel of zebrafish tissues. Identification of the members of the zebrafish $\mathrm{Na}, \mathrm{K}$-ATPase multigene family provides an initial framework for experiments designed to investigate the functional properties of these isoforms using this model system.

\section{RESULTS}

\section{Identification and Characterization of Zebrafish $\mathrm{Na}, \mathrm{K}-\mathrm{ATPase} \alpha$ Subunits}

We used BLAST (Altschul et al. 1990) and keyword searches of the GenBank database to identify zebrafish expressed sequence tags (ESTs) encoding $\mathrm{Na}, \mathrm{K}-\mathrm{ATPase} \alpha$ subunits. We sequenced the corresponding clones and identified overlapping regions. In cases where clones were unavailable or did not contain a complete open reading frame (ORF), full-length sequences were generated by a combination of reverse transcriptase-polymerase chain reaction (RT-PCR) and 5'-RACE (rapid amplification of cDNA ends). This approach resulted in the identification of full-length cDNAs encoding eight distinct $\alpha$ subunits. BLAST analysis of the deduced amino acid sequences indicates that each zebrafish clone exhibits greatest similarity with vertebrate $\mathrm{Na}, \mathrm{K}-\mathrm{ATPase} \alpha$ subunits. As shown in Table 1 , the zebrafish $\alpha$ subunits share $77 \%-92 \%$ amino acid identity with rat $\mathrm{Na}, \mathrm{K}-\mathrm{ATPa} e \mathrm{\alpha} \alpha 1, \alpha 2$, and $\alpha 3$ subunits, and $72 \%-78 \%$ identity with the rat $\alpha 4$ subunit. The sequences are considerably less similar to $\alpha$ subunits of other P-type ATPases including the gastric H,K-ATPase (61\%-64\% amino acid identity). Pairwise comparisons of zebrafish to rat $\alpha$ subunits indicate that zebrafish $\alpha$ subunit clones $1,3,4,7$, and 8 are most similar to the rat $\alpha 1$ subunit, clone 2 is most similar to the rat $\alpha 2$ subunit, whereas clones 5 and 6 are most similar to the rat $\alpha 3$ subunit. However, for six of the eight zebrafish clones, similarities to the rat $\alpha 1, \alpha 2$, and $\alpha 3$ subunits differ by no more than $3 \%$. Except for the $\alpha 3$-like clones 5 and 6 , simple sequence comparisons fail to provide a clear picture of which rat and fish genes are likely to be orthologous.

To better understand the relationship among zebrafish $\alpha$ subunits, we conducted sequence comparisons between each pair of zebrafish clones (Table 2). This analysis indicates that the $\alpha 1$-like clones 1,7 , and 8 share $90 \%-93 \%$ identity, whereas clones 5 and 6 share $94 \%$ identity. Clones 2, 3, and 4 show no more than $86 \%$ identity to any other $\alpha$ subunit
Table 2. Pariwise Comparisons among Zebrafish $\mathrm{Na}, \mathrm{K}-\mathrm{ATPase} \boldsymbol{\alpha}$ Subunit Isoforms

\begin{tabular}{lccccccc}
\hline & $\begin{array}{c}\text { Clone } \\
\mathbf{2}\end{array}$ & $\begin{array}{c}\text { Clone } \\
\mathbf{3}\end{array}$ & $\begin{array}{c}\text { Clone } \\
\mathbf{4}\end{array}$ & $\begin{array}{c}\text { Clone } \\
\mathbf{5}\end{array}$ & $\begin{array}{c}\text { Clone } \\
\mathbf{6}\end{array}$ & $\begin{array}{c}\text { Clone } \\
\mathbf{7}\end{array}$ & $\begin{array}{c}\text { Clone } \\
\mathbf{8}\end{array}$ \\
\hline Clone 1 & 83 & 81 & 85 & 85 & 85 & 93 & 91 \\
Clone 2 & & 77 & 78 & 83 & 83 & 84 & 83 \\
Clone 3 & & & 83 & 77 & 76 & 81 & 84 \\
Clone 4 & & & & 79 & 79 & 84 & 86 \\
Clone 5 & & & & & 94 & 85 & 84 \\
Clone 6 & & & & & & 85 & 84 \\
Clone 7 & & & & & & 90 \\
\hline
\end{tabular}

Numbers represent percent amino acid identity.

clone. Clones 3 and 4 are more similar to clones 1, 7, and 8 than to any of the other clones, whereas clone 2 shares equal similarity to all $\alpha$ subunit clones with the exception of clones 3 and 4 . These comparisons suggest that clones 1, 7, and 8, and clones 5 and 6 comprise two distinct subfamilies of zebrafish $\alpha$ subunit genes. Based on comparison with rat $\alpha$ subunits, clones 1,7 , and 8 are likely to represent a subfamily of $\alpha 1$-like genes, whereas clones 5 and 6 appear to represent a subfamily of $\alpha 3$-like genes. Clone 2 cannot be grouped with either subfamily.

A highly variable 10 amino acid-long segment located within the third cytoplasmic domain of the Na,K-ATPase $\alpha$ subunit has been proposed to represent an $\alpha$ subunit isoformspecific signature sequence (Pressley 1992). We therefore compared this region of zebrafish $\alpha$ subunits with the corresponding segment of Na,K-ATPase $\alpha$ subunits from a variety of vertebrate species. As shown in Figure 1, zebrafish clones 3, 4,7 , and 8 possess an $\alpha$ subunit signature sequence highly similar to that of $\alpha 1$ subunits of mammals, birds, amphibians, and teleosts. Although this region of clone 1 is more divergent, clone 1 still clusters with other members of the $\alpha 1$-like subfamily. The $\alpha$ subunit signature sequence in clone 6 is most similar to the corresponding segment found in the rat, chicken, and Tilapia $\alpha 3$ subunit. Clone 5 contains a signature sequence that shares similarities with mammalian $\alpha 2$ and $\alpha 3$ subunits. Clone 2 contains a signature sequence most similar to that of the $\alpha$ subunit from the Electrophorus electric organ and the mammalian and avian $\alpha 2$ subunits. This analysis supports the view that zebrafish clones $1,3,4,7$, and 8 are likely to represent orthologs of the mammalian $\alpha 1$ subunit, whereas clones 5 and 6 appear to represent orthologs of the mammalian $\alpha 3$ isoform. Additionally, these results raise the possibility that clone 2 is an ortholog of the mammalian $\alpha 2$ isoform.

\section{Phylogenetic Analysis of $\alpha$ Subunits}

To examine the evolutionary relationships between zebrafish

Table 1. Pairwise Comparisons between Zebrafish and Rat Na,K-ATPase $\alpha$ Subunits

\begin{tabular}{lcccccccc}
\hline & Clone 1 & Clone 2 & Clone 3 & Clone 4 & Clone 5 & Clone 6 & Clone 7 & Clone 8 \\
\hline Rat $\alpha$ 1 & 89 & 85 & 79 & 82 & 85 & 85 & 88 & 87 \\
Rat $\alpha 2$ & 86 & 86 & 78 & 81 & 85 & 85 & 86 & 84 \\
Rat $\alpha 3$ & 86 & 84 & 77 & 80 & 90 & 92 & 85 & 77 \\
Rat $\alpha$ 4 & 78 & 77 & 72 & 74 & 76 & 76 & 77 \\
\hline
\end{tabular}

Numbers represent percent amino acid identity.

\section{Genome Research}


Eel $\alpha 1$ Mullet $\alpha 1$ Bufo $\alpha 1$ Xenopus $\alpha 1$ Rat $\alpha 1$ Human $\alpha 1$ Chicken $\alpha 1$ Clone 1 Clone 3 Clone 4 Clone 7

Clone 8

Rat $\alpha 2$ Human $\alpha 2$ Chicken $\alpha 2$

Electr. $\alpha$

Clone 2

Rat $\alpha 3$ Human $\alpha 3$ Chicken $\alpha 3$ clone 5 Clone 6

Figure 1 Comparison of zebrafish and other vertebrate $\mathrm{Na}, \mathrm{K}$ ATPase $\alpha$ subunits. A segment of the third intracellular domain corresponding to residues $484-514$ of the rat $\alpha 1$ subunit is shown. The highly variable signature sequence is shown in bold. Sequences were aligned using CLUSTALW. Ellipses in sequences allow optimal alignment for amino acid insertions/deletions.

and mammalian $\mathrm{Na}, \mathrm{K}-\mathrm{ATPa} e \mathrm{\alpha}$ subunit genes, we conducted a phylogenetic analysis of $\alpha$ subunits using maximum parsimony (MP) (Felsenstein 1981) and distance matrix (DM) methods (Fitch and Margoliash 1967). This analysis included the zebrafish, representative mammalian, and all available nonmammalian vertebrate $\mathrm{Na}, \mathrm{K}$-ATPase $\alpha$ subunits. The consensus trees generated by this analysis are presented in Figure 2. The DM tree is shown on the left and the MP tree on the right. Within the $\alpha 1$ gene subfamily, the trees generated by both methods exhibit the expected phylogenetic relationships between species, although the basal position of the Torpedo $\alpha$ subunit is supported by only $67 \%(\mathrm{DM})$ or $35 \%$ (MP) of the trees generated by bootstrap analysis. Zebrafish clones 1, 3, 4, 7, and 8 cluster unambiguously with $\alpha 1$ sequences of other teleosts (DM: $100 \%$ of trees, MP: $99 \%$ of trees), as well as $\alpha 1$ sequences from all other species (DM: 96\% of trees, PM: $92 \%$ of trees). Clustering of zebrafish clones 5 and 6 with $\alpha 3$ sequences is also strongly supported (DM: $100 \%$ of trees, MP: $99 \%$ of trees). However, the two methods produced discordant results for zebrafish clone 2. The DM method clusters clone 2 and the Electrophorus $\alpha$ subunit with the mammalian and avian $\alpha 2$ subunits (60\% of trees), whereas this clustering was supported by only $14 \%$ of the MP trees. The consensus MP tree suggests an early divergence of clone 2 from the $\alpha 1, \alpha 2$, and $\alpha 3$ gene lineages (supported by $75 \%$ of MP trees). The results of this phylogenetic analysis indicate that zebrafish $\mathrm{Na}, \mathrm{K}$-ATPase $\alpha$ subunits can be grouped into three subfamilies; five can be assigned to the $\alpha 1$-like subfamily (clones $1,3,4,7$, and 8 ) while two can be assigned to the $\alpha 3$-like subfamily (clones 5 and 6). Clone 2 appears to represent a distinct $\alpha$ subunit subfamily, but the phylogenetic analysis does not es- tablish conclusively whether this clone is a true ortholog of the mammalian $\alpha 2$ subunit.

\section{Identification and Characterization of Zebrafish $\mathrm{Na}$,K-ATPase $\beta$ Subunits}

Zebrafish ESTs encoding multiple Na,K-ATPase $\beta$ subunits were identified by searches of the GenBank database. By sequencing the corresponding clones, we identified and characterized full-length ORFs encoding five distinct $\beta$ subunit isoforms. Sequence comparisons indicate that $\beta$ subunit clones $1 \mathrm{a}$ and $1 \mathrm{~b}$ are orthologs of the vertebrate $\beta 1$ subunit, sharing $66 \%$ identity with each other (Table 3 ) and $57 \%$ identity with the rat $\beta 1$ subunit (Table 4 ). Zebrafish $\beta$ subunit clone 2 shows only $37 \%-46 \%$ identity with the other zebrafish $\beta$ subunit clones (Table 3 ). However, this clone shares $74 \%$ identity with the rat $\beta 2$ subunit (Table 4 ), and therefore appears to represent an ortholog of the mammalian $\beta 2$ subunit. Zebrafish $\beta$ subunit clone 3a was identified previously as an ortholog of the mammalian $\beta 3$ subunit (Appel et al. 1996). Sequence analysis indicates that zebrafish clone $3 \mathrm{~b}$ shares $59 \%$ identity with clone $3 a$ and only $36 \%-46 \%$ identity with any of the other zebrafish $\beta$ subunit clones (Table 3). These results suggest that zebrafish clone $3 b$ is a second member of the $\beta 3$ gene subfamily.

An alignment of the deduced amino acid sequences of

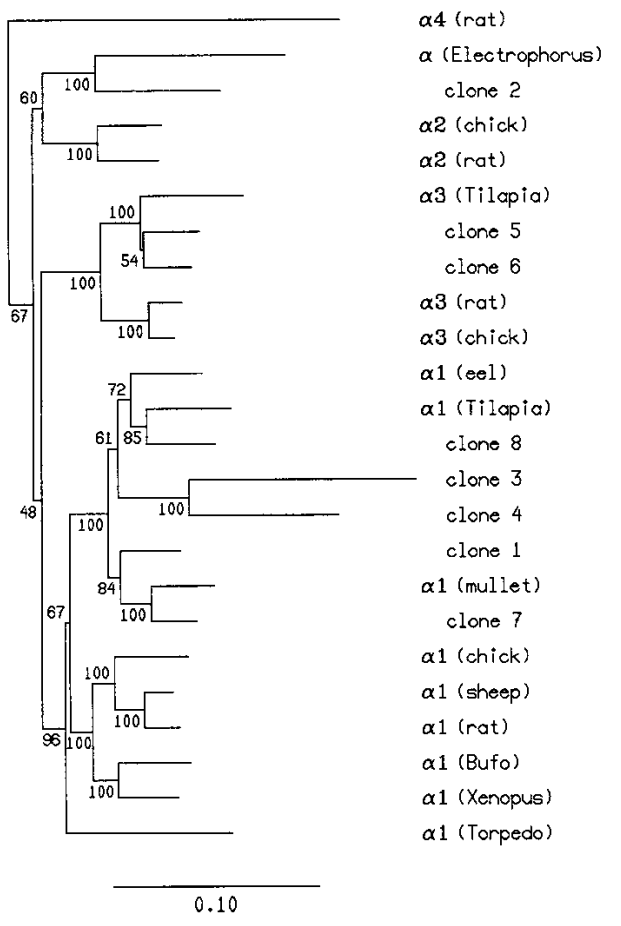

Figure 2 Phylogenetic analysis of vertebrate Na,K-ATPase $\alpha$ subunits. Consensus tree generated using the distance matrix method is shown at left with the scale of evolutionary distances below. Consensus tree generated using maximum parsimony method is at right. Numbers at each branch point indicate percent support from bootstrap analysis. Na, K-ATPase $\alpha$ subunit sequences were obtained from SwissProt or GenBank: rat $\alpha 1$ (atn_rat), $\alpha 2$ (atn2_rat), $\alpha 3$ (atn3_rat), and $\alpha 4$ (AAB81285); chicken $\alpha 1$ (atn1_chick), $\alpha 2$ (atn2_chick), and $\alpha 3$ (atn3 chick); sheep $\alpha 1$ (atn1 sheep); Bufo marinus $\alpha 1$ (atn1 bufma); Xenopus laevis $\alpha 1$ (atn1_xenla); European eel $\alpha 1$ (atna_angan); Tilipia mossambica $\alpha 1$ (AAD11455) and $\alpha 3$ (AAF75108); mullet $\alpha 1$ (atna_catco); Torpedo californica $\alpha 1$ (atna_torca). Electrophorus electricus $\alpha$ subunit sequence is from Kaya et al. (1997). 
Table 3. Pairwise Comparisons among Zebrafish $\mathrm{Na}, \mathrm{K}-\mathrm{ATP}$ ase $\boldsymbol{\beta}$ Subunit Isoforms

\begin{tabular}{lcccc}
\hline & Clone 1b & Clone 2 & Clone 3a & Clone 3b \\
\hline Clone 1a & \multirow{2}{*}{66} & 41 & 35 & 36 \\
Clone 1b & & 37 & 33 & 36 \\
Clone 2 & & & 45 & 46 \\
Clone 3a & & & & 59 \\
\hline
\end{tabular}

Numbers represent percent amino acid identity.

the five zebrafish $\mathrm{Na}$,K-ATPase $\beta$ subunit isoforms is shown in Figure 3. Each of the $\beta$ subunits contains an amino-terminal cytoplasmic domain, a single predicted transmembrane segment, and an extracellular carboxy-terminal domain containing six conserved cysteine residues and several potential sites for amino-linked glycosylation. A dendrogram showing sequence relationships among the zebrafish and other vertebrate $\beta$ subunits is presented in Figure 4 . This analysis clearly supports the idea that zebrafish clones $1 \mathrm{a}$ and $1 \mathrm{~b}$ are $\beta 1$ gene subfamily members, clone 2 is a $\beta 2$ subunit gene, and clones $3 \mathrm{a}$ and $3 \mathrm{~b}$ are members of the $\beta 3$ gene subfamily.

\section{Chromosomal Mapping of Zebrafish Na,K-ATPase $\alpha$ and $\beta$ Subunit Genes}

We determined the chromosomal positions of zebrafish $\mathrm{Na}, \mathrm{K}-$ ATPase genes using two radiation hybrid panels (Geisler et al. 1999; Hukriede et al. 1999) and a meiotic mapping panel (Woods et al. 2000). Twelve genes were mapped on the T51 panel, nine genes on the LN54 panel, and five genes on the HS panel. ESTs corresponding to $\alpha$ subunit clones 1 (AA495128) and 2 (AA494679), and $\beta$ subunit clone 3a had been mapped previously on the T51 panel (Geisler et al. 1999), and $\alpha$ subunit clones 1 and 8 had been mapped on the HS panel (Woods et al. 2000). A summary of the map positions of individual $\alpha$ and $\beta$ subunit genes is presented in Table 5 . Clones $1,3,4$, and 8 (which are members of the $\alpha 1$ gene subfamily) all mapped to linkage group (LG) 1 between microsatellite markers z9382 and z9394. These four genes are thus very tightly clustered in the genome. Clone 7 , the fifth $\alpha 1$-like gene, mapped to the middle of LG 9 and is closely linked to gabpa and $a c t b b$. We confirmed the location of zebrafish $\alpha$ subunit clone 2, which had been mapped previously to LG 2 between microsatellite markers z17291 and z1406 (Geisler et al. 1999). Clone 5, an $\alpha 3$-like gene, mapped to LG 19 between microsatellite markers z7450 and z3782. EST AW281746, corresponding to clone 5 , had been mapped independently to LG 19 (http://zfrhmaps.tch.harvard.edu/ZonRHmapper/). Clone 6 , the second member of the $\alpha 3$ gene subfamily,

\begin{tabular}{|c|c|c|c|c|c|}
\hline & $\begin{array}{c}\text { Clone } \\
1 \mathrm{a}\end{array}$ & $\begin{array}{c}\text { Clone } \\
\text { 1b }\end{array}$ & $\begin{array}{c}\text { Clone } \\
2\end{array}$ & $\begin{array}{c}\text { Clone } \\
3 a\end{array}$ & $\begin{array}{c}\text { Clone } \\
3 b\end{array}$ \\
\hline Rat $\beta 1$ & 57 & 57 & 44 & 39 & 37 \\
\hline Rat $\beta 2$ & 38 & 40 & 74 & 47 & 46 \\
\hline Rat $\beta 3$ & 37 & 36 & 64 & 50 & 45 \\
\hline Xenopus $\beta 3$ & 40 & 38 & 53 & 59 & 57 \\
\hline
\end{tabular}

Numbers represent percent amino acid identity. mapped to LG 16 between microsatellite markers z3072 and z6921. Clone $\beta 1$ a mapped to LG 6 in close proximity to $n d u f b 5$, whereas clone $\beta 1 \mathrm{~b}$ localized to LG 1 between microsatellite markers z5508 and z5058. $\beta$ subunit clone 2 , an ortholog of the mammalian $\beta 2$ subunit, mapped to LG 23 between microsatellite markers z9351 and z7243. We confirmed the location of clone $\beta 3 \mathrm{a}$ on LG 2 between microsatellite markers z4733 and z4300 (Geisler et al. 1999), whereas $\beta$ subunit clone $3 \mathrm{~b}$ mapped to LG 15 between microsatellite markers z6312 and z9214.

Based on the above analyses, we propose that the $\alpha 1$-like genes clustered on LG 1 and represented by clones $1,3,4$, and 8 be designated atp1a1a.1, atp1a1a.2, atp1a1a.3, and atp1a1a.4, respectively. The $\alpha 1$-like gene represented by clone 7 we have named $a t p 1 a 1 b$, whereas the gene encoded by clone 2 was named atp1a2. We have named the two $\alpha 3$-like genes represented by clones 5 and 6 atp $1 a 3 a$ and atp $1 a 3 b$, respectively. Our data indicates that zebrafish possess two Na,KATPase $\beta 1$-like genes (1a and $1 \mathrm{~b}$ ), which we have designated $a t p 1 b 1 a$ and $a t p 1 b 1 b$, respectively. The zebrafish ortholog of the mammalian $\beta 2$ subunit (clone 2) was named atp1b2, whereas the two zebrafish $\beta 3$-like clones ( $3 a$ and $3 b$ ) were named atp $1 b 3 a$ and $a t p 1 b 3 b$, respectively.

\section{Expression of Zebrafish $\alpha$ and $\beta$ Subunit Genes}

Expression of $\mathrm{Na}$,K-ATPase $\alpha$ and $\beta$ subunit mRNAs was analyzed by RT-PCR. Total RNA was prepared from a panel of adult zebrafish tissues including gut, eye, liver, heart, testis, and brain and used as template in RT-PCR reactions. The expression profile of zebrafish $\alpha$ subunits is shown in Figure 5. As a control, $\beta$-actin transcripts were amplified from individual RNA samples. Each RNA produced an RT-PCR product of the appropriate size, demonstrating the integrity of the samples. Analysis of the PCR products indicates that atp1a1a.1 (clone 1) is ubiquitously expressed, while atp1a2 (clone 2) is expressed in all tissues examined with the exception of testis. Clone 3 (atp1a1a.2), in contrast, is expressed in all tissues with the exception of brain and testis. Expression of atp1a1a.3 (clone 4) is expressed predominantly in gut, atp1a3a (clone 5) mRNA is present in gut, eye, testis, and brain, while $a t p 1 a 3 b$ (clone 6) mRNA is detected only in eye and brain. Expression of atp1a1b (clone 7) is restricted to eye, brain, and testis, while atp1a1a.4 (clone 8) mRNA is detectable in the gut, liver, and testis. The expression profile of zebrafish $\beta$ subunit clones is presented in Figure 6 . Among the $\beta 1$-like genes, clone $1 \mathrm{~b}(a t p 1 b 1 b)$ is ubiquitously expressed while clone 1a (atp1b1a) is expressed in all tissues except brain. Expression of $\beta$ subunit clone 2 (atp1b2) is restricted to eye and brain. Clone 3a (atp1b3a) is expressed predominantly in gut, eye, testis, and brain. Clone $3 \mathrm{~b}(a t p 1 b 3 b)$ is expressed in all tissues with the exception of heart. These results strongly indicate differential expression patterns for each of the $\alpha$ and $\beta$ subunit genes, and suggest that each gene is likely to subserve distinct functions.

\section{DISCUSSION}

We have identified and cloned eight Na,K-ATPase $\alpha$ subunit and five $\beta$ subunit genes from zebrafish. Sequence comparisons and phylogenetic analysis indicate that five of the zebrafish $\alpha$ subunit genes form an $\alpha 1$-like gene subfamily, two correspond to the $\alpha 3$ subfamily, and one appears to encode an $\alpha 2$-like subunit. Among the $\beta$ subunit genes, two are orthologs of the mammalian $\beta 1$ isoform, one represents a $\beta 2$

\section{Genome Research}


TM Domain

$\beta 1 \mathrm{a} \quad 1 \quad \ldots$ MPANKDGDGG. . .WKSF IWNSDKKEFLGRTGCSWLKIFIFYVIFYGCLAGIF IGTIQAMLLT

$\beta 1 \mathrm{~b} 1$...MPAQNKDDGG... WKKFVWNSEKKEFLGRTGGSWAKI FLFYLIFYGCLAGIFIGTIQILLLT

B2 1 MAKEDEK. KESGS. . . WKDFFWNPRTHELLGRTASSWGLILLFYLVFYTFLAGVFCLTMYVMLLT

$\beta 3 \mathrm{a} 1$ MSKKSENQRRAKSREQLERRDLHPRTGELFGRTARNWGLILLFYLVFYGFLAAMFVFTLWVMLQT

$\beta 3 \mathrm{~b} 1$ MANKEEKADEKQS. . SWKDF IYNPRTGEF I GRTASSWALIF LFYLVFYGF LAGMFTLTMWVMLQT

B1a 60 LSNYKPTYQDRVAPPGLSHSPRPDKAEISYNINDESTYMPYVNHIDAFLKAYNQDIQEDNTKFEL $\beta 1 \mathrm{~b} \quad 60$ LSDYKPTWQDRVAPPGLTHFPRSDKSEIAINLDDEVSFLNYVKVMREFLTSYDQEKQLDNMQFEN

$\beta 2 \quad 62$ LDDYQPTWQDRLATPGMMIRPKGEALEIVYSRENTESWELYVQALDSFLKPYNNSQQAVNNDDCTP

B3a 66 LNDDTPKYRDRVASPGLVIRPN. . SLNIEFNRSDPLEYGQYVQHLESFLHQYNDSEQAKN. DLCYG

$\beta 3 b \quad 64$ LDDHTPKYRDRVANPGLMIRPR. . SLDIAFNRSI PQQYSKYVQHLEAFLQSYNDSLQEAN . EPCQE

\begin{tabular}{|c|c|c|}
\hline $31 a$ & 6 & H \\
\hline$\beta 1 \mathrm{~b}$ & 126 & REWLGPCSGLDDP. \\
\hline 32 & 128 & D. . QFNIQEDSGNVRNNPKRSCRFNRTTLEDCSGLTDR. \\
\hline $3 a$ & 129 & .TVPEQDGE. \\
\hline $3 \mathrm{~b}$ & 127 & MYYFFOROY \\
\hline La & 192 & PPASNDSIPEAVRPKLQGN \\
\hline D & 189 & PPVSNESIPEEVQHKVQPY \\
\hline$\beta 2$ & 186 & ICGAKKEDAESIGEIAYFPPNGTF \\
\hline $3 a$ & 184 & VKPLQMTSISPMRTID \\
\hline $3 \mathrm{~b}$ & 182 & TVKGR. . WVFCRCSFTLTRAKS \\
\hline & 258 & ENIDYS . EKDRSQGRFDIKFTIK \\
\hline $11 \mathrm{~b}$ & 255 & PLVAIQFLN . ITPNTDMRIECKVYGENIYYH . DKDRYQGRFDVKFNIK \\
\hline$\beta 2$ & 236 & PLVAVKFMN. . ISFFTDVNVECKINSNTITEFSERDKFAGRVSFKLRVN \\
\hline & 228 & PLVAVKLLLKKEDYNSELIVECKVEGSNLKNNDERDKFLGRVTFRVLV? \\
\hline & 227 & DERDKFLGRVTFRINV \\
\hline
\end{tabular}

Figure 3 Comparison of zebrafish $\beta$ subunits were aligned using CLUSTALW. Ellipses in sequences allow optimal alignment for amino acid insertions/deletions. Conserved cysteines are shaded; potential amino-linked glycosylation sites are underlined. The single transmembrane (TM) domain is indicated by the solid line above the sequence. Amino acids are numbered to the left of each line.

brafish duplicates of $E N 1$ and $D L X 2$ on LG 1 and LG 9 supports the view that these are duplicate chromosome segments (Postlethwait et al. 2000). In the case of the zebrafish $\beta 2$ gene, which maps to LG 23 and Hsa $17 \mathrm{p} 13$, no additional genes have been identified that are syntenic with atp1b2 in both species. Instead, genes that are linked to $A T P 1 B 2$, such as TP53, are located on LG 5 and LG 15 in the zebrafish genome (Postlethwait et al. 2000).

The only zebrafish $\mathrm{Na}, \mathrm{K}$ ATPase subunit for which the mammalian ortholog has not been clearly resolved, either by sequence comparisons or phylogenetic analysis, is $\alpha$ subunit clone 2 (atp1a2). Comparative mapping, however, provides compelling evidence that the mammalian $\alpha 2$ subunit gene and zebrafish clone 2 are in fact orthologous. Our data indicate that clone 2 maps to zebrafish LG 2. In zebrafish, atp1a2 is tightly linked to copa and $m p z$ and the orthologs of these three genes in mouse are within an interval of less than $2 \mathrm{cM}$. In addition, several other loci show conserved syntenies with these chromosomes (Table 6). These results strongly indicate that zebrafish clone 2 and ATP1A2 are or-

ortholog, and two are orthologous to the mammalian $\beta 3$ subunit. The presence of orthologous genes corresponding to at least two $\alpha$ and three $\beta$ subunit isoforms in both zebrafish and mammals clearly implies that gene duplications producing multiple $\alpha$ and $\beta$ gene subfamilies predate the last common ancestor of teleosts and mammals.

We have utilized gene mapping to further study the evolution of zebrafish $\mathrm{Na}$,K-ATPase $\alpha$ and $\beta$ subunit genes. Map positions of $\mathrm{Na}, \mathrm{K}-\mathrm{ATP}$ ase genes and syntenic markers in zebrafish and humans are shown in Table 6. (Detailed genetic maps [M1-M5] are available as on-line supplementary material at http://www.genome.org.) In general, the mapping results tend to support the phylogenetic analysis. For example, the two zebrafish $\alpha 3$-like genes map to LG 16 and LG 19. Each of these linkage groups contains orthologs of additional human genes that map to Hsa $19 q 13$. The zebrafish $\beta 1$-like genes map to LG 1 and LG 6, and appear to share conserved syntenies with a set of human genes located on Hsa 1q. The $\beta 3$-like genes map to LG 2 and LG 15 and are syntenic with orthologs of a group of human genes that map to Hsa 3q. The zebrafish $\alpha 1$-like genes consist of one gene on LG 9 and a cluster of four genes tightly linked on LG 1. In humans, ATP1A1 and CASQ2 are tightly linked near the centromere on Hsa $1 \mathrm{p}$, and the orthologous zebrafish genes on LG 9 are also tightly linked. These results suggest the possibility that a segment of Hsa 1p and LG 9 may contain additional genes that are syntenic in both species. The cluster of $\alpha 1$-like genes on LG 1 represents a more complicated scenario. Conserved synteny between LG 1 and Hsa 1 involves several genes located on Hsa 1q, whereas ATP1A1 maps to Hsa 1p13. However, the presence of ze- thologous genes, but have diverged to such an extent that their sequence relationships are no longer clearly apparent. Such a relationship has been described for the zebrafish $h l \times 3$ and murine $D b \times 2$ homeodomain genes (Seo et al. 1999). It will be of considerable interest to determine whether sequence divergence between the zebrafish and mammalian $\alpha 2$ genes has led to functional differences between the mammalian and zebrafish $\alpha 2$ subunit polypeptides.

Analysis of the zebrafish genome indicates that zebrafish have undergone an additional round of genome duplication compared to mammals (Amores et al. 1998; Postlethwait et al. 1998). In the absence of gene loss, we would predict that each mammalian $\mathrm{Na}$,K-ATPase $\alpha$ and $\beta$ subunit gene should have two zebrafish orthologs. Consistent with this view, we have identified two zebrafish orthologs of the rat $\alpha 3, \beta 1$ and $\beta 3$ subunit genes. In contrast, we have found only single zebrafish orthologs of the rat $\alpha 2$ and $\beta 2$ subunits, suggesting that the second $\alpha 2$ and $\beta 2$ orthologs were lost during zebrafish evolution. It has been established that the degradation of one of two copies of a duplicate gene is a common phenomenon in gene evolution (Haldane 1933; Li 1980; Watterson 1983), whereas recent work suggests that many duplicate genes have been lost during zebrafish evolution (Postlethwait et al. 2000). Alternatively, it is possible that these genes are still present in the zebrafish genome, but are not represented in the cDNA libraries used to generate the zebrafish ESTs. Interestingly, five of the zebrafish $\alpha$ subunit genes appear to be orthologous to the mammalian $\alpha 1$ gene. Thus for the $\alpha 1$ gene subfamily, there must have been additional gene duplication events in addition to the genome-wide duplication. 

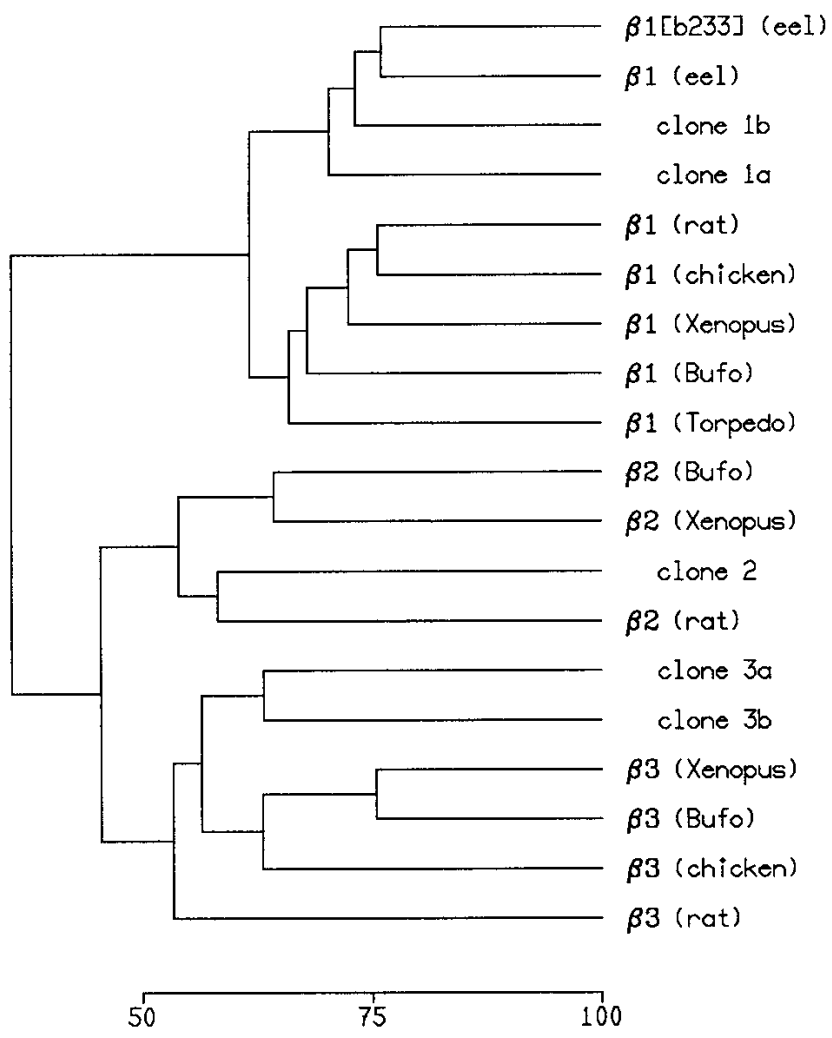

Figure 4 Sequence relatedness of Na,K-ATPase $\beta$ subunits. Dendrogram of amino acid sequence similarity was constructed using the PILEUP program. The scale at the bottom indicated percent identity between $\beta$ subunits. Sequences were obtained from SwissProt or GenBank: European eel $\beta 1$ (atnb_angan) and $\beta 1$ isoform b233 (CAB85586); rat $\beta 1$ (atnb_rat), $\beta 2$ (atnc_rat), and $\beta 3$ (atnd_rat); chicken $\beta 1$ (atnb_chick) and $\beta 3$ (atnd_chick); Xenopus laevis $\beta 1$ (AAA82967), $\beta 2$ (CAC08235), and $\beta 3$ (atnd_xenla), Bufo marinus $\beta 1$ (atnb_bufma), $\beta 2$ (atnc_bufma), and $\beta 3$ (atnd_bufma); Torpedo californica $\beta 1$ (atnb_torca).

Because our mapping data places four of the $\alpha 1$-like genes within a tight cluster on LG 1 , we surmise that these loci have arisen by local, tandem duplications that have arisen after the hypothesized genome duplication event. Retention of a high proportion of $\mathrm{Na}, \mathrm{K}-\mathrm{ATP}$ ase $\alpha$ and $\beta$ subunit gene duplicates suggests that these genes are more likely to possess specialized, rather than redundant, functional properties. In this context, it should be noted that a zebrafish ortholog of the mammalian $\alpha 4$ subunit has not as yet been identified. The mammalian $\alpha 4$ subunit is expressed exclusively in testis, a tissue from which no zebrafish ESTs have been reported. It will be interesting to determine whether this $\alpha$ subunit isoform is present in zebrafish spermatozoa.

The expression patterns of $\mathrm{Na}, \mathrm{K}$-ATPase $\alpha$ and $\beta$ subunit genes in zebrafish are quite distinctive, with no two $\alpha$ or $\beta$ subunit genes exhibiting the same expression profile. The expression of $\alpha$ subunit genes is particularly striking in liver, where mRNAs corresponding to four of the eight zebrafish $\alpha$ subunit isoforms are detected. This contrasts with the situation in rodents, where the $\alpha 1$ subunit is the only isoform that appears to be expressed (Shyjan and Levenson 1989). In mammals, the $\alpha 3$ gene is expressed predominantly within neurons (Cameron et al. 1994) and in retinal photoreceptors
(Schneider et al. 1991). Both of the zebrafish $\alpha 3$ orthologs show expression in brain and eye. However, clone 5 (atp1a3a) is also expressed in gut, suggesting an additional role for this isoform in the digestive tract. More precise localization of the two $\alpha 3$ genes in zebrafish will be required to determine whether the $\alpha 3$ genes are likely to perform similar functions in mammals and fish. The expression pattern for the five zebrafish $\alpha 1$-like genes is also somewhat surprising. Each $\alpha 1$ gene shows an overlapping yet distinctive expression pattern. Expression of clone 1 is ubiquitous. Clone 4 (atp1a1a.3) is expressed in all tissues except brain, whereas clone 3 (atp1a1a.2) is expressed in all tissues except brain and testis. Expression of clone 7 (atp1a1b) is restricted to brain, eye, and testis, whereas expression of clone 8 (atp1a1a.4) is only detected in gut, liver, and testis among organs tested. These expression profiles are consistent with the view that the $\alpha 1$ like genes most likely subserve distinct functions. In situ hybridization analysis of $\alpha 1$-like mRNA expression should help to discriminate whether these genes are differentially expressed within a tissue. Differential cellular localization would provide further support for the view that these genes are not merely redundant but play specialized physiological roles in zebrafish.

A fundamental unresolved issue concerning $\mathrm{Na}, \mathrm{K}$ ATPase is why there are so many different $\alpha$ and $\beta$ subunit isoforms. In mammals, each of the four $\alpha$ subunits appears capable of associating with any of the three $\beta$ subunits, potentially giving rise to $>12$ structurally distinct isoenzymes. The potential for isoenzyme heterogeneity is even greater in zebrafish. If each zebrafish $\alpha$ subunit can associate with each of the five $\beta$ subunit isoforms, 40 different zebrafish $\mathrm{Na}, \mathrm{K}$ ATPase isoenzymes could potentially be formed. It seems unlikely that all $40 \alpha / \beta$ subunit combinations are actually formed in vivo. Analysis of $\alpha$ and $\beta$ subunit expression within specific cell types should provide a more precise picture of which $\alpha / \beta$ subunit combinations may actually be produced within a given tissue or cell type. It also seems highly unlikely that all $\alpha / \beta$ subunit combinations form holoenzymes that are functionally equivalent. The view that at least some of the isoenzymes express distinct functional properties is a more appealing hypothesis. Functional characterization of mammalian Na,K-ATPase has failed to delineate clear biochemical differences between isoenzymes. Furthermore, no naturally occurring mutations in mouse or human sodium pump genes have yet been described. It has thus been difficult to associate a physiological or behavioral deficit with the function of a particular isoenzyme. The identification of the cohort of $\mathrm{Na}, \mathrm{K}-\mathrm{ATP} a \mathrm{se}$ genes expressed in zebrafish facilitates the application of conditional knockdown approaches to elucidate the roles these genes play in zebrafish development and physiology.

\section{METHODS}

\section{Cloning of Zebrafish $\alpha$ and $\beta$ Subunits}

cDNAs encoding zebrafish Na,K-ATPase $\alpha$ and $\beta$ subunits were identified by searches of the GenBank EST database. Clones were obtained from Genome Systems, Research Genetics, or RZPD (Resource Center for the German Genome Project, Berlin). ESTs that were unavailable from these sources were generated by RT-PCR using protocols described in the SuperScript RT-PCR kit (Life Technologies). Clones that did not encode a complete ORF were extended using a 5'-RACE kit (Life Technologies) using whole adult zebrafish mRNA as template. cD-

\section{Genome Research}


Table 5. Map Positions of Zebrafish and Orthologous Human and Mouse Na,K-ATPase $\alpha$ and $\beta$ Subunit Genes

\begin{tabular}{|c|c|c|c|c|c|c|c|c|c|}
\hline \multirow[b]{2}{*}{ Clone } & \multirow{2}{*}{$\begin{array}{l}\text { Accession } \\
\text { no. }\end{array}$} & \multirow[b]{2}{*}{ Forward primer } & \multirow[b]{2}{*}{ Reverse primer } & \multicolumn{2}{|c|}{ Zebrafish } & \multicolumn{2}{|c|}{ Human ortholog } & \multicolumn{2}{|c|}{ Mouse ortholog } \\
\hline & & & & Locus & LG & Name & Location $^{e}$ & Name & Chromosome $^{\mathrm{f}}(\mathrm{cM})$ \\
\hline $\begin{array}{l}\alpha \text { Clone } 1 \\
\alpha \text { Clone } 3 \\
\alpha \text { Clone } 4 \\
\alpha \text { Clone } 7 \\
\alpha \text { Clone } 8\end{array}$ & $\begin{array}{l}\text { AF286373 } \\
\text { AF286374 } \\
\text { AF308598 } \\
\text { AY008375 } \\
\text { AY008376 }\end{array}$ & $\begin{array}{l}\text { gtaggtctccctctccaccc } \\
\text { atacatcctgcgacggaatc } \\
\text { gcatggaagttgctgtcaga } \\
\text { gagaaagctcatccttagac } \\
\text { gaggttgggtggaacaagaa }\end{array}$ & $\begin{array}{l}\text { gcgccttcccctactcact } \\
\text { caccagattctttatcgcttttc } \\
\text { ctgcacatgttcccaagaga } \\
\text { acagcaaaactactggaac } \\
\text { attgactgaaaatgggcaga }\end{array}$ & $\begin{array}{l}\text { atp1a1a.1 } \\
\text { atp1a1a.2 } \\
\text { atp1a1a.3 } \\
\text { atp1a1b } \\
\text { atp1a1a.4 }\end{array}$ & $\begin{array}{l}1^{\mathrm{bc}} \\
1^{\mathrm{a}} \\
1^{\mathrm{a}} \\
9^{\mathrm{a}} \\
1^{\mathrm{a}}\end{array}$ & ATP1A1 & $1 \mathrm{p} 13.1$ & Atp1a1 & $3(48.4)$ \\
\hline$\alpha$ Clone 2 & AF286373 & ggtgaacgactctccagctc & gaagggtgtgactctggga & atp1a2 & $2^{\mathrm{bc}}$ & ATP1A2 & $1 q 23-24$ & Atp1a2 & $1(94.2)$ \\
\hline $\begin{array}{l}\alpha \text { Clone } 5 \\
\alpha \text { Clone } 6\end{array}$ & $\begin{array}{l}\text { AF308599 } \\
\text { AY008374 }\end{array}$ & $\begin{array}{l}\text { ggatagaagagggaggagg } \\
\text { agctcttccgtgctcaagtc }\end{array}$ & $\begin{array}{l}\text { gtattgcgatgtgttgtggac } \\
\text { agccgtgtgaaaatacatgc }\end{array}$ & $\begin{array}{l}\text { atp1a3a } \\
\text { atp1a3b }\end{array}$ & $\begin{array}{l}19^{\mathrm{ad}} \\
16^{\mathrm{a}}\end{array}$ & ATP1A3 & $19 q 13.2$ & Atp1a3 & $7(5.5)$ \\
\hline $\begin{array}{l}\beta \text { Clone } 1 \mathrm{a} \\
\beta \text { Clone } 1 \mathrm{~b}\end{array}$ & $\begin{array}{l}\text { AF286375 } \\
\text { AF308597 }\end{array}$ & $\begin{array}{l}\text { agccatgggacgttcattta } \\
\text { cgtgaaattccaatggatgc }\end{array}$ & $\begin{array}{l}\text { ccacacgagggcagaaatac } \\
\text { aatgcagatgttggcattga }\end{array}$ & $\begin{array}{l}\text { atp1b1a } \\
\text { atp1b1b }\end{array}$ & $\begin{array}{l}6^{\mathrm{a}} \\
1^{\mathrm{a}}\end{array}$ & ATP1B1 & $1 \mathrm{q} 24.2$ & Atp1bl & $1(86.8)$ \\
\hline$\beta$ Clone 2 & AF286376 & ccgagttcagcgagagagac & cacctcccacaatctcctgt & atp1b2 & $23^{\mathrm{a}}$ & ATP1B2 & $17 p 13.1$ & Atp1b2 & $11(40)$ \\
\hline $\begin{array}{l}\beta \text { Clone 3a } \\
\beta \text { Clone 3b }\end{array}$ & $\begin{array}{l}X 89722 \\
\text { AF293369 }\end{array}$ & $\begin{array}{l}\text { ttccgggtcctggtgaccgaat } \\
\text { tgtccatcacgtccattttg }\end{array}$ & $\begin{array}{l}\text { gggttaaaattcaattaaatgttcg } \\
\text { accttcacgagcacaggttt }\end{array}$ & $\begin{array}{l}\text { atp1b3a } \\
\text { atp1b3b }\end{array}$ & $2^{\mathrm{b}}$ & ATP1B3 & $3 q 23$ & Atp1b3 & $9(51)$ \\
\hline $\begin{array}{l}\text { aThis paper. } \\
\text { b'Geisler et a } \\
{ }^{\mathrm{b}} \mathrm{http}: / / z e b r \\
{ }^{\mathrm{d}} \mathrm{http} / / / \mathrm{zfrhr} \\
\mathrm{e}^{\mathrm{e}} \text { Human ma } \\
{ }^{\mathrm{f}} \text { Mouse map }\end{array}$ & $\begin{array}{l}\text { al. } 1999 \text { htt } \\
\text { rafish.stanfor } \\
\text { maps.tch.ha } \\
\text { ap positions } \\
\text { p positions }\end{array}$ & $\begin{array}{l}\text { tp://wwwmap.tuebingen } \\
\text { rd.edu/genome/HeatSho } \\
\text { arvard.edu/ZonRHmapper } \\
\text { were obtained from OM } \\
\text { were obtained from MGD }\end{array}$ & $\begin{array}{l}\text { ר.mpg.de/). } \\
\text { ck99 } \\
\text { er } \\
\text { MIM (http://w } \\
\text { D (http://ww }\end{array}$ & 1.9 & & & & & \\
\hline
\end{tabular}

NAs were sequenced using an ABI 377 automated DNA sequencer.

$\alpha$ subunit clone 1 (atp1a1a.1; GenBank accession no. AF286372) was obtained from Genome Systems and corre-

\section{$\mathrm{Gu}$ Ey $\mathrm{Li} \quad \mathrm{He} \quad \mathrm{Te} \quad \mathrm{Br}$ WF}

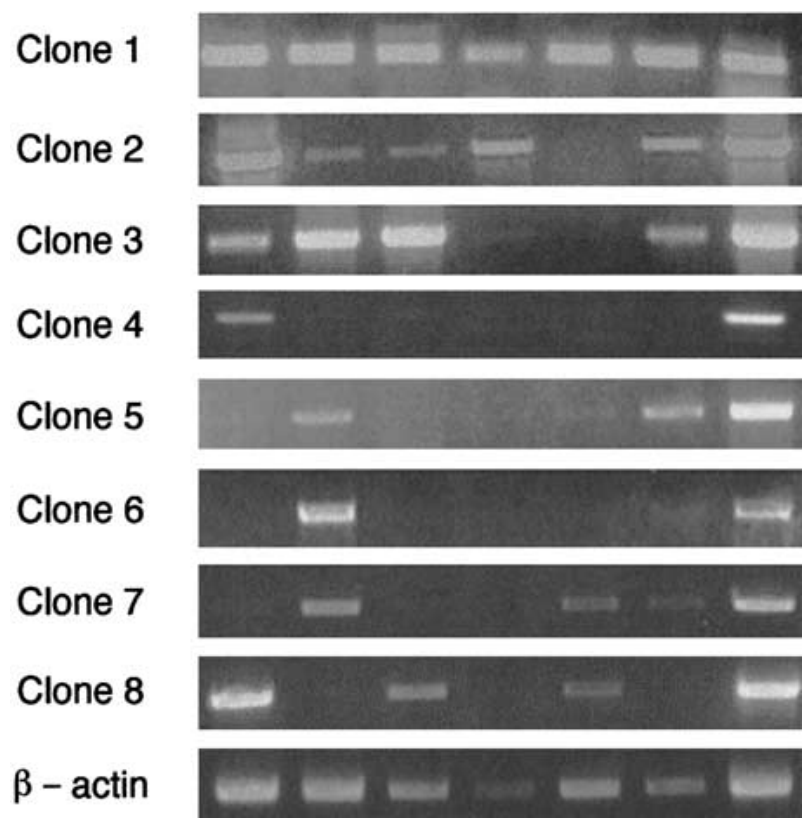

Figure 5 Expression of Na,K-ATPase $\alpha$ subunit mRNAs in zebrafish tissues. Total RNA was prepared from adult zebrafish and used as template for RT-PCR. Amplification products were analyzed by electrophoresis on a $1 \%$ agarose gel. (Gu) gut; (Ey) eye; (Li) liver; (He) heart; (Te) testis; (Br) brain; (WF) shole fish. $\beta$-actin controls are shown at the bottom. sponds to ESTs AA495128 and AA495435 (GenBank). The cDNA is $3474 \mathrm{bp}$ in length, whereas the complete ORF spans nucleotides 174-3260. $\alpha$ subunit clone 2 (atp1a2; GenBank accession no. AF286373) is a 3889-bp long cDNA containing a complete ORF that spans nucleotides 101-3154. Nucleotides 1461-3889 were determined by sequencing clone ICRFp524B1612 (RZPD) which corresponds to EST AA494679 (GenBank). Nucleotides 568-1460 were generated by RT-PCR and the $5^{\prime}$ end generated by $5^{\prime}$-RACE using nested primers complementary to nucleotides $622-642$ and 582-601. $\alpha$ subunit clone 3 (atp1a1a.2; GenBank accession no. AF286374) is a 3235-bp long cDNA containing a complete ORF that spans nucleotides 62-3133. Nucleotides 296-3255 were obtained by sequencing clone MPMGp609H2236Q.1 (RZPD) which corresponds to EST AI878291 (GenBank). The 5' end of the cDNA was generated by $5^{\prime}$-RACE using nested primers complementary to nucleotides $311-332$ and $344-363$. $\alpha$ subunit clone 4

\section{Gu Ey Li $\mathrm{He} \quad \mathrm{Te} \quad \mathrm{Br}$ WF}

Clone 1a

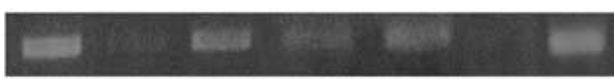

Clone 1b

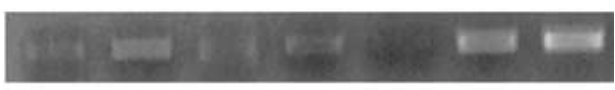

Clone 2

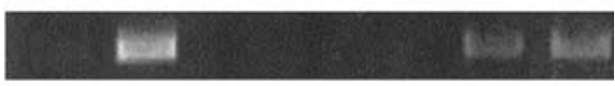

Clone 3a

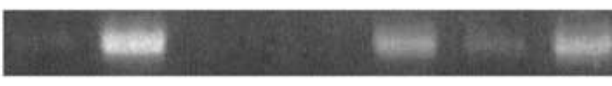

Clone $3 b$

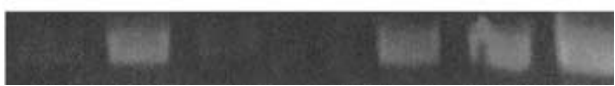

Figure 6 Expression of $\mathrm{Na}, \mathrm{K}-\mathrm{ATP}$ ase $\beta$ subunit mRNAs in zebrafish tissues. Total RNA was prepared from adult zebrafish and used as template for RT-PCR. Amplification products were analyzed by electrophoresis on a 1\% agarose gel. (Gu) gut; (Ey) eye; (Li) liver; (He) heart; (Te) testis; (Br) brain; (WF) whole fish. 
Rajarao et al.

Table 6. Markers Syntenic with Na,K-ATPase Genes in Zebrafish and Human

\begin{tabular}{|c|c|c|c|c|}
\hline \multirow[b]{2}{*}{ Name } & \multicolumn{2}{|c|}{ Zebrafish gene } & \multicolumn{2}{|c|}{ Human ortholog } \\
\hline & Accession No. & Map position ${ }^{a}$ & Name & Map position \\
\hline $\begin{array}{l}\text { atp1a1a.1-.4 } \\
\text { atp1b1b }\end{array}$ & & $\begin{array}{l}1-0.0 \\
1-21.8\end{array}$ & $\begin{array}{l}\text { ATP1A1 } \\
\text { ATP1B1 }\end{array}$ & $\begin{array}{l}1 \mathrm{p} 13.1 \\
1 \mathrm{q} 24.2\end{array}$ \\
\hline oct1 & AF030519 & $1-0.0$ & POU2F1 & $1 q 22-q 23$ \\
\hline (b1zf1) & AW174816 & $1-0.0$ & BLZF1 & $1 q 24$ \\
\hline (capn9) & Al544664 & $1-91.5$ & CAPN9 & $1 q 42$ \\
\hline atp1a2 & & $2-108.6$ & ATP1A2 & $1 q 21-q 23$ \\
\hline$(\sec 2211)$ & Al497465 & $2-40.4$ & SEC22L1 & $1 q 21.2-$ \\
\hline$(\mathrm{mpz})$ & AW174967 & 2-108.6 & MPZ & $1 q 22-q 23$ \\
\hline ср1а2 & U10330 & $2-55.8$ & PLA2G4A & $1 q 25$ \\
\hline (arf1) & Al558333 & $2-12.3$ & ARF1 & $1 q 42$ \\
\hline (fh) & AA555477 & $2-155.3$ & $\mathrm{FH}$ & $1 \mathrm{q} 42.1$ \\
\hline atp1b3a & & $2-50.0$ & ATP1B3 & $3 q 23$ \\
\hline & Al497391 & $2-50.0$ & TF & $3 q 21$ \\
\hline (copb2) & Al415987 & $2-95.6$ & СOPB2 & $3 q 23$ \\
\hline (d1g1) & Al723230 & $2-12.3$ & DLG1 & $3 q 29$ \\
\hline (loc57018) & AW165033 & $2-87.8$ & LOC57018 & $3 q$ \\
\hline (arpc4) & AA542497 & $2-50.0$ & ARPC4 & $3 p$ \\
\hline (dkfzp564k247) & Al477599 & $2-7.3$ & DKFZP564K247 & $3 p$ \\
\hline (epha3) & AW175051 & $2-95.6$ & EPHA3 & $3 p 11.2$ \\
\hline atp1b1a & & $6-65.3$ & ATP1B1 & $1 q 24.2$ \\
\hline (mypt2) & AW173939 & $6-59.6$ & MYPT2 & $1 \mathrm{q} 32.1$ \\
\hline atp1a1b & & $9-66.5$ & ATP1A1 & $1 \mathrm{p} 13.1$ \\
\hline (casq2) & AA497210 & $9-60.5$ & CASQ2 & $1 \mathrm{p} 13.3-\mathrm{p} 11$ \\
\hline (ddah1) & Al722688 & $9-110.0$ & DDAH1 & $1 \mathrm{p} 22$ \\
\hline atp1b3b & & 15-32.7 & ATP1B3 & $3 q 23$ \\
\hline gap43 & L27645 & $15-132.5$ & GAP43 & $3 q^{13}$ \\
\hline chd & AF034606 & $15-127.8$ & CHRD & $3 q 27$ \\
\hline atp1a3b & & $16-22.1$ & ATP1A3 & $19 q 13.2$ \\
\hline gsk3a & A)223501 & $16-30.0$ & GSK3A & $19 q 13$ \\
\hline (kiaa0306) & AI584937 & $16-30.0$ & KIAA0306 & $19 q 13$ \\
\hline apoeb & Y13652 & $16-40.9$ & APOE & $19 q 13$ \\
\hline (ceacam1) & Al353126 & $16-32.8$ & CEACAM1 & $19 q 13.2$ \\
\hline (rps9) & Al353657 & $16-72.5$ & RPS9 & $19 q 13.4$ \\
\hline (dnase2) & Al330733 & $16-99.2$ & DNASE2 & $19 \mathrm{p} 13.2$ \\
\hline atp1a3a & & $19-33.8$ & ATP1A3 & $19 q 13.2$ \\
\hline (erf) & (Al658144) & $19-36.4$ & ERF & $19 q 13$ \\
\hline (apoea) & (AI544900) & $19-51.6$ & APOE & $19 q 13$ \\
\hline atp1b2 & & $23-124.4$ & ATP1B2 & 17p13.1 \\
\hline
\end{tabular}

aLinkage group and position (in cM) on HS map.

(atp1a1a.3; GenBank accession no. AF308598) is a 3275-bp long cDNA containing a complete ORF that spans nucleotides 71-3145. Nucleotides 623-3275 were determined by sequencing clone UCDMp574K2119Q2 (RZPD) which corresponds to EST AW184276 (GenBank). The 5' end of the cDNA was obtained by $5^{\prime}$-RACE using nested primers complementary to nucleotides 706-723 and 753-772. $\alpha$ subunit clone 5 (atp1a3a; GenBank accession no. AF308599) was generated by RT-PCR using primers based on the sequence of ESTs AW281430 and AW281746 (GenBank). The cDNA is $3664 \mathrm{bp}$ in length and the complete ORF spans nucleotides 185-3256. $\alpha$ subunit clone 6 (atp1a3b; GenBank accession no. AY008374) was generated by RT-PCR. The cDNA is 3309-bp long and the complete ORF spans nucleotides 18-3089. Two overlapping cDNA fragments spanning nucleotides 284-3309 were generated by RT-PCR using primers based on the sequences of ESTs AW280277, AW077565, and AW279681 (GenBank). The 5' end of the cDNA was generated by 5'-RACE using nested primers complementary to nucleotides 234-303 and nucleotides 317-338. $\alpha$ subunit clone 7 (atp1a1b; GenBank accession no. AY008375) was generated by RT-PCR. The cDNA is $3284 \mathrm{bp}$ in length and the complete ORF spans nucleotides 15-3092. Two overlapping cDNA fragments spanning nucleotides 237-3284 were generated by RT-PCR based on the sequences of ESTs AW281423, AW077399, and AW077182 (GenBank). The 5' end of the cDNA was generated by 5 '-RACE using nested primers complementary to nucleotides 584-564 and nucleotides 358-341. $\alpha$ subunit clone 8 (atp1a1a.4; GenBank accession no. AY008376) is a 3262-bp long cDNA containing a complete ORF that spans nucleotides 76-3150. Nucleotides 112-3262 were determined by sequencing clone CHBOp575E1024Q3 (RZPD) which corresponds to EST AW422519 (GenBank). The 5' end of the cDNA was generated by $5^{\prime}$-RACE using nested primers complementary to nucleotides 351-371 and 149-168.

$\beta$ subunit clone 1a (atp1b1a; GenBank accession no. AF286375) was obtained from Research Genetics and corresponds to EST AI384184 (GenBank). The cDNA is 1477-bp 
long and the complete ORF spans nucleotides 71-991. $\beta$ subunit clone 1b (atp1b1b; GenBank accession no. AF308597) was obtained from RZPD (Clone number UCDMp611D1320) and corresponds to EST AW280780 (GenBank). The cDNA is 2384 nucleotides long and the complete ORF spans nucleotides 120-1028. $\beta$ subunit clone 2 (atp1b2; GenBank accession no. AF286376) was obtained from Research Genetics and corresponds to EST AI629140 (GenBank). The cDNA is 1076 nucleotides in length and the complete ORF spans nucleotides 127-984. $\beta$ subunit clone 3b (atp1b3b; GenBank accession no. AF293369) was obtained from Research Genetics and corresponds to EST AI722718 (GenBank). The cDNA is 1755 nucleotides long and the complete ORF spans nucleotides 80907. $\beta$ subunit clone 3a (atp1b3a; GenBank accession no. X89722) has been described previously by Appel et al. (1996).

\section{Phylogenetic Analysis}

Full-length $\mathrm{Na}$,K-ATPase $\alpha$ and $\beta$ subunit amino acid sequences were aligned using either the P ILEUP (Devereux et al. 1984), or CLUSTALW (Thompson et al. 1994) programs. Phylogenetic analysis of $\mathrm{Na}, \mathrm{K}$-ATPase $\alpha$ subunits by maximum parsimony and distance matrix methods was performed using the Phylip suite of programs (version 3.573c) described by Felsenstein (1981). Regions in which alignments were ambiguous due to amino acid insertions or deletions were omitted, leaving 993 amino acids available for phylogenetic analysis (aligned with amino acids 30-497 and 501-1023 of rat $\alpha 1$ ). Maximum parsimony trees were calculated using PROTPARS. Evolutionary distance trees were constructed by using the algorithm of Fitch and Margoliash (1967). For each method, tree reliability was estimated by analysis of 100 half jackknife subreplicates. Trees were rooted using the Na,K-ATPase $\alpha$ subunit from sea urchin, Hemicentrotus pulcherrimus (MitsunagaNakatsubo et al. 1996).

\section{Chromosomal Localization of $\alpha$ and $\beta$ Subunit Genes}

Zebrafish $\alpha$ and $\beta$ subunit genes were mapped using the Goodfellow T51 radiation hybrid (RH) panel (Kwok et al. 1998), the Ekker LN54 RH panel (Hukriede et al. 1999), and the heat shock (HS) double haploid meiotic mapping panel (Kelly et al. 2000; Woods et al. 2000). The T51 panel was purchased from Research Genetics. PCR products specific for each zebrafish $\alpha$ and $\beta$ subunit gene were amplified using primers corresponding to unique $3^{\prime}$ UTR sequences. Primers were designed using the program Primer3 (S. Rozen and H.J. Skaletski, unpubl., data available at http://www-genome.wi. mit.edu/genome_software/other/primer3.html). A complete list of primers used to determine linkage assignments is detailed in Table 5. PCR reactions were performed in duplicate on the RH panels using conditions described previously (Geisler et al. 1999; Hukriede et al. 1999). PCR reaction products were fractionated on $2 \%$ agarose gels, and each sample scored for presence or absence of the zebrafish-specific amplicon. Linkage assignments were computed using the resources of the Tübingen Zebrafish Mapping Facility (http://www.map. tuebingen.mpg.de) and the Igor Dawid Web site (http:// mgchd1.nichd.nih.gov:8000/zfrh/beta.cgi). Sodium pump genes were mapped on the HS panel using single strand conformation polymorphism analysis as described by Woods et al. (2000). One of the primers in each PCR reaction was endlabeled using $\gamma-{ }^{32} \mathrm{P}$ ATP and products were detected by autoradiography after fractionation on acrylamide gels. The strain distribution patterns on the HS panel were analyzed using MapManager (http://mcbio.med.buffalo.edu/mapmgr.html). All loci (with the exception of atp1b1a) were mapped on at least two of the three mapping panels. Loci mapped only on the RH panels were placed on the HS map by interpolation of markers mapped on both panels. Comparative mapping of sodium pump genes between Danio rerio and Homo sapiens was performed as described previously (Postlethwait et al. 2000).

\section{Expression of Zebrafish $\alpha$ and $\beta$ Subunit mRNAs}

Several tissues including gut, eye, liver, heart, testis, and brain were dissected manually from adult zebrafish. Tissues were homogenized in TRIzol Reagent (Life Technologies) and total RNA extracted according to the method of Chomczynski and Sacchi (1987). Organ-specific RNA (0.3-0.5 $\mu \mathrm{g})$ was used as template to generate single stranded cDNA using the SuperScript First Strand Synthesis kit (Life Technologies). One twentieth of the reaction product was used in each PCR reaction. PCR was carried out with Platinum Pf $x$ DNA Polymerase (Life Technologies) using a RoboCycler Gradient Temperature Cycler (Stratagene). An initial $3 \mathrm{~min}$ denaturation step at $94^{\circ} \mathrm{C}$ was followed by 34 cycles at $94^{\circ} \mathrm{C}$ for $30 \mathrm{~s}, 55-60^{\circ} \mathrm{C}$ for $30 \mathrm{~s}$, and $72^{\circ} \mathrm{C}$ for $1 \mathrm{~min}$. A final elongation step was carried out at $72^{\circ} \mathrm{C}$ for $10 \mathrm{~min}$. PCR products were analyzed by electrophoresis on a 1\% agarose gel. (Sequences of gene-specific primers used for RT-PCR are available as supplementary material [Table A] at http://www.genome.org.)

\section{ACKNOWLEDGMENTS}

This work was supported by NIH grants HL 39263 (to R.L.), CA 73935 (to K.C.C.), and 1-G20-RR11724 (to J.H.P.). We are especially grateful to Dr. Jessica Moore for help with zebrafish dissections, and Dr. Robert Geisler for computing linkage assignments.

\section{NOTE ADDED IN PROOF}

After submission of this manuscript, we sequenced a second $\mathrm{Na}, \mathrm{K}-\mathrm{ATPase} \beta 2$ subunit (atp1b2b, accession no. AF373976) with $74 \%$ amino acid identity to atp1b2 (now renamed atp1b2a).

The publication costs of this article were defrayed in part by payment of page charges. This article must therefore be hereby marked "advertisement" in accordance with 18 USC section 1734 solely to indicate this fact.

\section{REFERENCES}

Altschul, S., Gish, W., Miller, W., Myers, E., and Lipman, D. 1990 Basic local alignment search tool. I. Mol. Biol. 215: 403-410.

Amores, A., Force, A., Yan, Y.-L., Joly, L., Amemiya, C., Ho, R.K., Langeland, J., Prince, V., Wang, Y.-L., Westerfield, M., et al. 1998. Zebrafish hox clusters and vertebrate genome evolution. Science 282: 1711-1714.

Appel, C., Gloor, S., Schmalzing, G., Schachner, M., and Bernhardt, R. 1996. Expression of a Na,K-ATPase beta3 subunit during development of the zebrafish central nervous system. J. Neurosci. Res. 46: 551-564

Besirli, C.G., Gong, T.-W.L., and Lomax, M.I. 1998. The Atp1b3 gene for the Na,K-ATPase $\beta 3$ subunit maps to mouse chromosome 9, and a related gene, Atp1b3-rs, maps to mouse chromosome 3. Mamm. Genome 9: 171-172.

Cameron, R., Klein, L., Shyjan, A.W., Rakic, P., and Levenson, R. 1994. Neurons and astroglia express distinct subsets of Na,K-ATPase $\alpha$ and $\beta$ subunits. Mol. Brain Res. 21: 333-343.

Cantley, L.C. 1981. Structure and mechanism of the Na,K-ATPase. Curr. Top. Bioenerg. 11: 201-237.

Chomczynski, P. and Sacchi, N. 1987. Single-step method of RNA isolation by acid guanidinium thiocyanate-phenol-choloform extraction. Anal. Biochem. 162: 156-159.

Crambert, G., Hasler, U., Beggah, A.T., Yu, C., Modyanov, N.N., Horisberger, J.D., Lelievre, L., and Geering, K. 2000. Transport and pharmacological properties of nine different human $\mathrm{Na}$, K-ATPase isozymes. J. Biol. Chem. 275: 1976-1986.

Devereux, J., Haeberli, P., and Smithies, O. 1984. A comprehensive set of sequence analysis programs for the VAX. Nucleic Acids Res. 12: $387-395$.

Felsenstein, J. 1981. Evolutionary trees from DNA sequences: A maximum likelihood approach. J. Mol. Evol. 17: 368-376.

Fitch, W.M. and Margoliash, E. 1967. Construction of phylogenetic 


\section{Rajarao et al.}

trees. Science 155: 279-284.

Geisler, R., Rauch, G.J., Baier, H., van Bebber, F., Brobeta, L., Dekens, M.P., Finger, K., Fricke, C., Gates, M.A., Geiger, H., et al. 1999. A radiation hybrid map of the zebrafish genome. Nat. Genet. 23: $86-89$.

Haldane, J. 1933. The part played by the recurrent mutation in evolution. Am. Nat. 67: 5-9.

Hukriede, N., Joly, L., Tsang, M., Miles, J., Tellis, P., Epstein, J., Barbazuk, W., Li, F., Paw, B., Postlethwait, J., et al. 1999. Radiation hybrid mapping of the zebrafish genome. Proc. Natl. Acad. Sci. 96: 9745-9750.

Jewell, E.A. and Lingrel, J.B. 1991. Comparison of the substrate dependence properties of the rat Na,K-ATPase $\alpha 1, \alpha 2$, and $\alpha 3$ isoforms expressed in HeLa cells. J. Biol. Chem. 266: $16925-16930$

Jørgensen, P.L. 1974. Purification and characterization of $\left(\mathrm{Na}^{+}\right.$ $+\mathrm{K}^{+}$)-ATPase. IV. Estimation of the purity and of the molecular weight and polypeptide content per enzyme unit in preparations from the outer medulla of rabbit kidney. Biochim. Biophys. Acta 356: $53-67$.

Kaya, S., Yokoyama, A., Imagawa, T., Taniguchi, K., Froehlich, J.P., and Albers, R.W. 1997. Cloning of the eel electroplax Na,K-ATPase $\alpha$ subunit. Ann. N.Y. Acad. Sci. 834: 129-131.

Kelly, P., Chu, F., Woods, I., Ngo-Hazelett, P., Cardozo, T., Huang, H., Kimm, F., Liao, L., Yan, Y.-L., Zhou, Y., et al. 2000. Genetic linkage mapping of zebrafish genes and ESTs. Genome Res. 10: $558-567$.

Kwok, C., Korn, R.M., Davis, M.E., Burt, D.W., Critcher, R. McCarthy, L., Paw, B.H., Zon, L.I., Goodfellow, P.N., and Schmitt, K. 1998. Characterization of whole genome radiation hybrid mapping resources for non-mammalian vertebrates. Nucleic Acids Res. 26: 3562-3566.

Lemas, M.V., Yu, H.V., Takeyasu, K., Kone, B., and Fambrough, D.M 1994. Assembly of the Na,K-ATPase $\alpha$-subunit isoforms with $\mathrm{Na}, \mathrm{K}$-ATPase $\beta$-subunit isoforms and $\mathrm{H}, \mathrm{K}$-ATPase $\beta$-subunit. $J$. Biol. Chem. 269: 18651-189655.

Levenson, R. 1994. Isoforms of the Na,K-ATPase: Family members in search of function. Rev. Physiol. Biochem. Pharmacol 123: 1-45.

Li, W.-H., 1980. Rate of gene silencing at duplicate loci: A theoretical study and interpretation of data from tetraploid fishes. Genetics 95: 237-258.

Malik, N., Canfield, V.A., Beckers, M., Gros, P., and Levenson, R. 1996. Identification of the mammalian $\mathrm{Na}, \mathrm{K}-\mathrm{ATPase} \beta 3$ subunit. J. Biol. Chem. 271: 22754-22758.

Malik, N., Canfield, V., Sanchez-Watts, G., Watts, A.G., Scherer, S., Beatty, B.G., Gros, P., and Levenson, R. 1998. Structural organization and chromosomal localization of the human $\mathrm{Na}, \mathrm{K}-\mathrm{ATP}$ ase $\beta 3$ subunit gene and pseudogene. Mamm. Genome 9: $136-143$.
Mitsunaga-Nakatsubo, K., Yamazaki, K., Hatoh-Okazaki, M., Kawashita, H., Okamura, C., Akasaka, K., Shimada, H., and Yasumasu, I. 1996. cDNA cloning of $\mathrm{Na}, \mathrm{K}$-ATPase $\alpha$-subunit from embryos of the sea urchin, Hemicentrotus pulcherrimus. Zoolog. Sci. 13: $833-841$.

Postlethwait, J., Yan, Y.-L., Gates, M., Horne, S., Amores, A., Brownlie, A., Donovan, A., Egan, E., Force, A., Gong, Z., et al. 1998. Vertebrate genome evolution and the zebrafish gene map. Nat. Genet. 18: 345-349.

Postlethwait, J., Woods, I., Ngo-Hazelett, P., Yan, Y., Kelly, P., Chu, F., Huang, H., Hill-Force, A., and Talbot, W. 2000. Zebrafish comparative genomics and the origins of vertebrate chromosomes. Genome Res. 10: 1890-902

Pressley, T.A. 1992. Phylogenetic conservation of isoform-specific regions within a subunit of Na,K-ATPase. Am. J. Physiol. 262: C743-C751.

Schneider, B.G., Shyjan, A.W., and Levenson, R. 1991. Co-localization and polarized distribution of $\mathrm{Na}, \mathrm{K}$-ATPase $\alpha 3$ and $\beta 2$ subunits in photoreceptor cells. J. Histochem. Cytochem. 39: $507-517$

Seo, H.-C., Nilsen, F., and Fjose, A. 1999. Three structurally and functionally conserved Hlx genes in zebrafish. Biochim. Biophys. Acta. 1489: 323-335.

Shamraj, O.I. and Lingrel, J.B. 1994. A putative fourth Na,K-ATPase $\alpha$-subunit gene is expressed in testis. Proc. Natl. Acad. Sci. 91: 12952-12956.

Shyjan, A.W. and Levenson, R. 1989. Antisera specific for the $\alpha 1, \alpha 2$, $\alpha 3$ and $\beta$ subunits of the Na,K-ATPase: Differential expression of $\alpha$ and $\beta$ subunit in rat tissue membranes. Biochemistry 28: $4531-4535$.

Thompson, J., Higgins, D., and Gibson, T. 1994. http://www.ebi. ac.uk/clustalw Underhill, A.D., Canfield, V.A., Dahl, J.P., Gros, P., and Levenson, R. 1999. The Na,K-ATPase $\alpha 4$ gene (Atp1a4) encodes a ouabain-resistant $\alpha$ subunit and is tightly linked to the $\alpha 2$ gene (Atp1a2) on mouse chromosome 1. Biochemistry 38: $14746-14751$.

Watterson, G. 1983. On the time for gene silencing at duplicate loci. Genetics 105: 745-766.

Woo, A.L., James, P.F., and Lingrel, J.B. 1999. Characterization of the fourth $\alpha$ isoform of the Na,K-ATPase. J. Membrane Biol. 169: $39-44$.

Woods, I.G., Kelly, P.D., Chu, F., Ngo-Hazelett, P., Yan, Y.-L., Huang, H., Postlethwait, J.H., and Talbot, W.S. 2000. A comparative map of the zebrafish genome. Genome Res. 10: 1903-1914.

Received February 21, 2001; accepted in revised form April 16, 2001. 


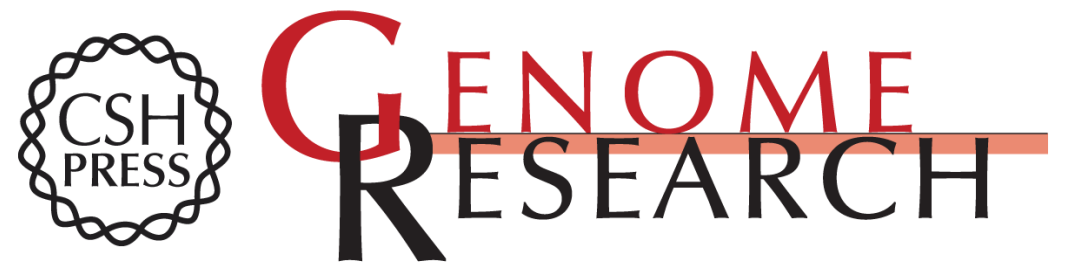

\section{The Repertoire of Na,K-ATPase $\alpha$ and $\beta$ Subunit Genes Expressed in the Zebrafish, Danio rerio}

S. Johannes R. Rajarao, Victor A. Canfield, Manzoor-Ali P.K. Mohideen, et al.

Genome Res. 2001 11: 1211-1220

Access the most recent version at doi:10.1101/gr.186001

Supplemental Material

References

License

Email Alerting Service
http://genome.cshlp.org/content/suppl/2001/07/02/11.7.1211.DC1

This article cites 34 articles, 13 of which can be accessed free at: http://genome.cshlp.org/content/11/7/1211.full.html\#ref-list-1

Receive free email alerts when new articles cite this article - sign up in the box at the top right corner of the article or click here.

\section{Affordable, Accurate Sequencing.}

